\title{
Short communication: Genetic relationships of milk coagulation properties with body condition score and linear type traits in Holstein-Friesian cows ${ }^{1}$
}

\author{
M. Cassandro, ${ }^{*}$ M. Battagin, $\dagger$ M. Penasa, ${ }^{* 2}$ and M. De Marchi* \\ *Department of Agronomy, Food, Natural Resources, Animals and Environment, University of Padova, Viale dell'Università 16, \\ 35020 Legnaro (PD), Italy \\ †Associazione Nazionale Allevatori Frisona Italiana, 26100 Cremona, Italy
}

\section{ABSTRACT}

Milk coagulation properties (MCP) are gaining popularity among dairy cattle producers and the improvement of traits associated with MCP is expected to result in a benefit for the dairy industry, especially in countries with a long tradition in cheese production. The objectives of this study were to estimate genetic correlations of MCP with body condition score (BCS) and type traits using data from first-parity Italian Holstein-Friesian cattle. The data analyzed consisted of 18,460 MCP records from 4,036 cows with information on both BCS and conformation traits. The cows were daughters of 246 sires and the pedigree file included a total of 37,559 animals. Genetic relationships of MCP with BCS and type traits were estimated using bivariate animal models. The model for MCP included fixed effects of stage of lactation, and random effects of herd-test-date, cow permanent environment, additive genetic animal, and residual. Fixed factors considered in the model for BCS and type traits were herd-date of evaluation and interaction between age at scoring and stage of lactation of the cow, and random terms were additive genetic animal, cow permanent environment, and residual. Genetic relationships between MCP and $\mathrm{BCS}$, and MCP and type traits were generally low and significant only in a few cases, suggesting that MCP can be selected for without detrimental effects on BCS and linear type traits.

Key words: milk coagulation ability, type trait, body condition score, genetic correlation

\footnotetext{
Received March 20, 2014.

Accepted October 8, 2014.

${ }^{1} \mathrm{M}$. Cassandro coordinated the project and designed the dataset on milk coagulation properties. M. Battagin performed statistical analyses. M. Cassandro, M. Battagin, and M. Penasa wrote the first draft of the manuscript. M. De Marchi reviewed the paper. All authors read and approved the final version of the work.

${ }^{2}$ Corresponding author: mauro.penasa@unipd.it
}

\section{Short Communication}

Milk coagulation properties (MCP) have been proposed as technological traits to improve the efficiency of the cheese-making process and cheese yield (RiddellLawrence and Hicks, 1989; Pretto et al., 2013) and are especially popular in countries with a long tradition in cheese making. In Italy, more than $70 \%$ of the overall milk production is used to manufacture cheese and thus $\mathrm{MCP}$ are of great importance. The assessment of MCP at a population level depends on the availability of fast and cheap technologies such as mid-infrared spectroscopy (MIRS), which has been successfully used for the prediction of MCP (De Marchi et al., 2013, 2014; Penasa et al., 2014). Several studies have estimated the additive genetic variance and heritability of coagulation properties, especially rennet coagulation time (RCT, min) and curd firmness $\left(\mathbf{a}_{\mathbf{3 0}}, \mathrm{mm}\right.$; e.g., Ikonen et al., 2004; Penasa et al., 2010), suggesting that selection for enhancing these characteristics is feasible.

An important functional and managerial trait in dairy cow is BCS, which is useful to appraise the body fat reserves and energy status of cattle. Changes in BCS reflect both the body composition and energy balance of the animal, which are critical for metabolic stability, health, and fertility. Impaired reproductive performance has a large economic impact on efficiency of dairy production, and this problem has been exacerbated by selection for milk yield (Pryce et al., 1998). The improvement of milk production has led to a worsening of the average body condition of the cow, partly as a consequence of antagonistic genetic correlations between milk yield and BCS (Pryce et al., 2001; Kadarmideen and Wegmann, 2003).

The Italian Holstein Friesian Cattle Breeders Association (ANAFI) has been collecting linear type traits and BCS on first-lactation cows since 1984 and 2007, respectively (Battagin et al., 2012, 2013). Conformation traits are scored using a 1- to 50-point scale system, and BCS is based on a 1 (thin) to 5 (fat) scale with 0.25-point increments (Edmonson et al., 1989). Whereas genetic evaluation for conformation has a long history in Italian Holstein-Friesian cattle, evaluation for 
BCS has been introduced only recently. No estimates of genetic relationships of MCP with BCS and linear type traits are currently available in the literature and thus the objective of this study was to assess genetic correlations between MCP and BCS and conformation using data of first-lactation Holstein-Friesian cows.

Since 2011, the laboratory of the Breeders Association of Veneto region (Padova, Italy) has added the analysis of MCP to its portfolio. Individual milk samples are routinely collected in dairy herds of Veneto region and analyzed for traditional quality traits and MCP using MIRS models installed on Milko-Scan FT6000 (Foss Electric A/S, Hillerød, Denmark). Coefficients of determination in cross-validation were 0.76 and 0.70 for $\mathrm{RCT}$ and $\mathrm{a}_{30}$, respectively [full details on fitting statistics of MIRS equations used to predict MCP can be retrieved from De Marchi et al. (2012, 2013)]. First-lactation records from September 2011 to January 2013 were obtained from the aforementioned laboratory and edited following Tiezzi et al. (2013). Briefly, Holstein-Friesian cows between 5 and 365 DIM, with at least 2 test-day records and belonging to herd-test-date (HTD) classes with a minimum of 3 contemporary animals were considered. Sires were required to have at least 5 daughters in 3 herds. Records with RCT outside the range 5 to 30 min were removed from the dataset because this is the range on which the calibration model was built. Moreover, records on RCT and $\mathrm{a}_{30}$ were discarded if they deviated more than 3.5 SD from the respective mean, or if the corresponding record for milk yield, fat content, or protein content were beyond the mean \pm 3.5 SD. Body condition score and linear type traits were recorded by ANAFI once in first-parity cows between 20 and 38 mo of age, and a description is presented in Table 1. At least 2 contemporary animals in a given herd-date of evaluation were required. After editing, 18,460 records of RCT and $\mathrm{a}_{30}$ from 4,036 cows progeny of 246 bulls and with information on BCS and linear type traits were available for genetic analysis. The pedigree file (37,559 animals) was supplied by ANAFI, and included individuals with phenotypic records and all their ancestors up to 8 generations back.

Genetic relationships of MCP with BCS and type traits were obtained under 40 sequential bivariate analyses in which a milk coagulation characteristic (RCT or $\mathrm{a}_{30}$ ) was analyzed simultaneously with BCS or a type trait. The model for MCP included fixed systematic effects of stage of lactation (10 classes of DIM, the first being a class from 5 to $30 \mathrm{~d}$, followed by 8 classes of $30 \mathrm{~d}$ each, and the last being a class from 270 to 365 d), and the model for BCS and type traits included fixed systematic effects of herd-date of evaluation (435 levels) and the interaction between age at scoring and stage of lactation of the cow (116 levels). Age at scoring was grouped in 12 classes, the first being a class from 20 to $22 \mathrm{mo}$, classes that were in the middle of this distribution were 1 mo each, and the last being a class from 33 to 38 mo. The general form of the linear animal model was as follows:

$$
\mathbf{y}=\mathbf{X b}+\mathbf{Z}_{1} \mathbf{h}+\mathbf{Z}_{2} \mathbf{p}+\mathbf{Z}_{3} \mathbf{a}+\mathbf{e},
$$

where $\mathbf{y}$ is the vector of observations for RCT, $\mathrm{a}_{30}$, $\mathrm{BCS}$, or type trait; $\mathbf{b}$ is the vector of fixed effects as previously described; $\mathbf{h}$ is the vector of random effects of HTD (only for MCP); $\mathbf{p}$ is the vector of cow permanent environmental effects; $\mathbf{a}$ is the vector of random effects of additive genetic animal; and $\mathbf{e}$ is the vector of random residuals. $\mathbf{X}, \mathbf{Z}_{1}, \mathbf{Z}_{2}$, and $\mathbf{Z}_{3}$ are incidence matrices of appropriate order relating the corresponding effects to the dependent variable. For the random effects, the following (co)variance structure was assumed:

$$
\operatorname{Var}\left[\begin{array}{c}
\mathbf{a}_{1} \\
\mathbf{a}_{2} \\
\mathbf{h}_{1} \\
\mathbf{p}_{1} \\
\mathbf{p}_{2} \\
\mathbf{e}_{1} \\
\mathbf{e}_{2}
\end{array}\right]=\left[\begin{array}{ccccccc}
\mathbf{A} \sigma_{a 1}^{2} & \mathbf{A} \sigma_{a 1 a 2} & 0 & 0 & 0 & 0 & 0 \\
& \mathbf{A} \sigma_{a 2}^{2} & 0 & 0 & 0 & 0 & 0 \\
& & \mathbf{I} \sigma_{h 1}^{2} & 0 & 0 & 0 & 0 \\
& & & \mathbf{I} \sigma_{p 1}^{2} & \mathbf{I} \sigma_{p 1 p 2} & 0 & 0 \\
& \text { symm. } & & & \mathbf{I} \sigma_{p 2}^{2} & 0 & 0 \\
& & & & & \mathbf{I} \sigma_{e 1}^{2} & 0 \\
& & & & & & \mathbf{I} \sigma_{e 2}^{2}
\end{array}\right],
$$

where $\sigma_{\mathrm{a} 1}^{2}$ and $\sigma_{\mathrm{a} 2}^{2}$ are the additive genetic variances of traits 1 (RCT or $\mathrm{a}_{30}$ ) and 2 (BCS or type trait), respectively; $\sigma_{\mathrm{h} 1}^{2}$ is the HTD variance of trait $1 ; \sigma_{\mathrm{p} 1}^{2}$ is the cow permanent environmental variance of trait $1 ; \sigma_{\mathrm{e} 1}^{2}$ and $\sigma_{\mathrm{e} 2}^{2}$ are the residual variances of traits 1 and 2 , respectively; $\sigma_{\mathrm{a} 1 \mathrm{a} 2}$ is the additive genetic covariance between traits 1 and 2; $\mathbf{I}$ is an identity matrix of appropriate order; and $\mathbf{A}$ is the numerator of Wright's relationship matrix among animals. Due to the data structure (repeated measures for RCT and $\mathrm{a}_{30}$, and single measures for type traits and BCS) and to avoid possible biases in the estimation of genetic covariances, the residual covariance between MCP and type traits or BCS was estimated by including a permanent variance for traits measured once $\left(\sigma_{p 2}^{2}\right)$ and a permanent environmental covariance $\left(\sigma_{p 1 p 2}\right)$ between repeated and singly measured traits. Following Hanford et al. (2002), the estimated $\sigma_{p 1 p 2}$ corresponds to the residual covariance between traits, and for singly measured characteristics, whereas the actual residual variance is given by $\left(\sigma_{\mathrm{e} 2}^{2}+\sigma_{p 2}^{2}\right)$. Morrissey et al. (2012) and Careau et al. (2013) reported that the aforementioned approach does not entail that it is possible to assess a permanent en- 
Table 1. Statistical description of milk coagulation properties $^{1}(\mathrm{n}=18,460)$, and linear type traits, ${ }^{2}$ final score, and BCS $(\mathrm{n}=4,036)$

\begin{tabular}{|c|c|c|c|c|c|}
\hline \multirow[b]{2}{*}{ Trait } & \multirow[b]{2}{*}{ Mean } & \multirow[b]{2}{*}{$\mathrm{SD}$} & \multirow[b]{2}{*}{ Definition } & \multicolumn{2}{|c|}{ Descriptor } \\
\hline & & & & Minimum & Maximum \\
\hline \multicolumn{6}{|l|}{ Milk coagulation property } \\
\hline $\mathrm{RCT}$, min & 20.7 & 3.92 & Time interval from the addition of rennet to milk until the beginning of coagulation & Short & Long \\
\hline $\mathrm{a}_{30}, \mathrm{~mm}$ & 22.7 & 8.78 & Firmness of the curd 30 min after rennet addition & Weak & Firm \\
\hline \multicolumn{6}{|c|}{ 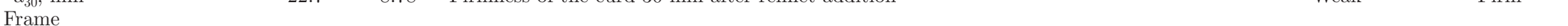 } \\
\hline Stature & 31.2 & 5.81 & Measured from top of the spine between hips to ground & Short & Tall \\
\hline Chest width & 27.0 & 5.18 & Measured from the inside surface between the top of the front legs & Weak & Strong \\
\hline Body depth & 30.0 & 4.87 & Distance between the top of spine and bottom of barrel at last rib, the deepest point & Shallow & $\begin{array}{l}\text { Extremely } \\
\text { deep }\end{array}$ \\
\hline Angularity & 29.3 & 4.49 & Angle and spring of the ribs & Nonangular & $\begin{array}{l}\text { Highly } \\
\text { angular }\end{array}$ \\
\hline Rump angle & 23.9 & 5.93 & Measured as the angle of the rump structure from hooks (hips) to pins & High pins & Low pins \\
\hline Rump width & 25.0 & 6.09 & Distance between the most posterior points of pin bones & Narrow & Wide \\
\hline Conformation & 25.7 & 5.60 & Standard of breed (feet and legs, and udder are not included) & $\begin{array}{l}\text { Not agree } \\
\text { to the breed } \\
\text { standard }\end{array}$ & $\begin{array}{l}\text { Breed } \\
\text { standard }\end{array}$ \\
\hline \multicolumn{6}{|l|}{ Feet and legs } \\
\hline Rear leg set side view & 24.0 & 6.15 & Angle measured at the front of the hock, side view & Straight & Sickled \\
\hline Rear leg set rear view & 25.7 & 6.41 & Direction of the rear feet, rear view & Hocked in & $\begin{array}{l}\text { Correctly } \\
\text { straight }\end{array}$ \\
\hline Foot angle & 25.2 & 5.68 & Angle at the front of the rear hoof measured from the floor to the hairline at the right hoof & Low & High \\
\hline Feet and legs functionality & 22.8 & 6.01 & Functionality of feet and legs & $\begin{array}{l}\text { Lowly } \\
\text { functional }\end{array}$ & $\begin{array}{l}\text { Highly } \\
\text { functional }\end{array}$ \\
\hline \multicolumn{6}{|l|}{ Udder } \\
\hline Fore udder attachment & 23.8 & 6.25 & Strength of the attachment of the fore udder to the abdominal wall & Weak & Strong \\
\hline Rear udder height & 27.2 & 5.60 & Distance between the bottom of the vulva and the milk secreting tissue & Low & High \\
\hline Udder depth & 27.9 & 7.39 & Distance from the lowest part of the udder floor to the hock & Deep & Shallow \\
\hline Rear udder width & 31.6 & 4.88 & Width of the high part of udder & Narrow & Wide \\
\hline Central ligament & 31.1 & 5.46 & Depth of cleft, measured at the base of the rear udder & Weak & Strong \\
\hline Front teat placement & 24.9 & 3.94 & Position of the front teats from center of quarter, viewed from the rear & $\begin{array}{l}\text { Outside of } \\
\text { quarter }\end{array}$ & $\begin{array}{l}\text { Inside of } \\
\text { quarter }\end{array}$ \\
\hline Teat length & 21.0 & 5.49 & Length of the front teat & Short & Long \\
\hline Final score ${ }^{3}$ & 80.1 & 2.08 & Combination of structure (20\%), dairy strength $(20 \%)$, feet and legs $(20 \%)$, and udder $(40 \%)$ & & \\
\hline $\mathrm{BCS}^{4}$ & 2.91 & 0.48 & Visual measure of the covering of fat over the pelvic and lumbar regions & Thin & Fat \\
\hline
\end{tabular}

. $\mathrm{RCT}=$ rennet coagulation time; $\mathrm{a}_{30}=$ curd firmness $30 \mathrm{~min}$ after rennet addition.

D) ${ }^{2}$ Linear type traits are evaluated on a 1- to 50-point scale.

$\stackrel{3}{\bar{D}}$ Final score is evaluated on a 50- to 100-point scale. Cows with final score lower than 70 are not enrolled in the herd book, and primiparous cows can obtain a maximum score of 88 .

Body condition score was measured according to the method of Edmonson et al. (1989), based on a 1- to 5-point scale with 0.25-unit increments 
vironmental effect for traits measured only once for each animal, but the implementation in mixed models could enable the statistical estimation of biologically relevant correlations between the residuals of nonrepeated performances and the nongenetic but repeatable variance component of repeated measures. Analyses were performed using an average-information REML algorithm in AIREMLf90 program (Misztal, 2008).

For MCP, heritability was calculated as the ratio of additive genetic variance to phenotypic variance, which was the sum of additive genetic, HTD, cow permanent environmental, and residual variances, whereas for BCS and type traits heritability was the sum of additive genetic, cow permanent environmental, and residual variances. Standard errors of heritability and genetic correlations were approximated using the delta method described by Lynch and Walsh (1998). Significance of the additive genetic covariance was determined using likelihood-ratio tests to compare models with and without this random effect, and genetic correlations were considered significant if the associated covariance component was also significant.

Rennet coagulation time and $\mathrm{a}_{30}$ averaged $20.7 \mathrm{~min}$ and $22.7 \mathrm{~mm}$, respectively (Table 1), with a coefficient of variation that was much greater for $\mathrm{a}_{30}(38.7 \%)$ than RCT $(18.9 \%)$. These results confirm previous findings of Tiezzi et al. (2013) who reported mean values of 20.6 min and $21.7 \mathrm{~mm}$ for RCT and $\mathrm{a}_{30}$ predicted by MIRS, respectively, using repeated records from primiparous and multiparous Holstein cows. Cassandro et al. (2008) found much better coagulation characteristics of milk from Holstein cows (parity 1 to 7 ) sampled once compared with the present study, with average values of $16.9 \mathrm{~min}$ for RCT and $32.0 \mathrm{~mm}$ for $\mathrm{a}_{30}$. The poorer values of technological properties from the present work compared with those of Cassandro et al. (2008) could be related to a general deterioration of MCP or to different techniques used for the assessment of milk coagulation ability. In fact, in the study of Cassandro et al. (2008), RCT and $\mathrm{a}_{30}$ were determined using a computerized renneting meter, whereas in the present study they were predicted by MIRS. Pretto et al. (2011) and Cipolat-Gotet et al. (2012) demonstrated that MCP determined with different methodologies led to different results.

Means and SD for linear type traits ranged from 21.0 (teat length) to 31.6 (rear udder width) and from 3.94 (front teat placement) to 7.39 (udder depth), respectively (Table 1). The final score, which combines 4 general characteristics of the cow with different weights (20\% structure, 20\% dairy strength, 20\% feet and legs, and $40 \%$ udder) and ranges from 50 (insufficient) to 100 (excellent) with 1 point increment, averaged 80.1 and exhibited very low variation (coefficient of varia- tion $=2.6 \%$ ). The limited variation for this trait was expected as the range of utilization of the scale is quite narrow: in fact, only cows with final score equal to or greater than 70 are enrolled in the herd-book, and first-lactation cows can reach a maximum score of 88. Average values of conformation traits from the present study are comparable to national statistics of ANAFI (2013). Results for stature, body depth, angularity, rear udder width, and central ligament show that Italian Holstein-Friesian cows were selected for a balance between production and type traits compared with Canadian Holsteins, which were selected more for type, and US Holsteins, which were selected more for production (Miglior et al., 2005).

The mean and SD for BCS were 2.91 and 0.48, respectively (Table 1 ), which are similar to findings (3.01 and 0.46) of Battagin et al. (2013) obtained in first-parity Italian Holstein-Friesian cows, but using much more data. Several authors investigated BCS in Holstein-Friesian populations using the 5-point system of Edmonson et al. (1989), and results were generally comparable with those of the present study. In Ireland, Berry et al. (2011) reported mean and SD of 3.01 and 0.40, respectively. Pryce et al. (2001) calculated mean and SD of 2.53 and 0.37, respectively, in Scottish Holsteins. Finally, Kadarmideen and Wegmann (2003) reported mean and SD of 2.74 and 0.35 , respectively, in Swiss Holsteins.

Because genetic parameters were obtained from 40 bivariate analyses in which a milk coagulation property $\left(\mathrm{RCT}\right.$ or $\mathrm{a}_{30}$ ) was analyzed simultaneously with BCS or a type trait, additive genetic SD and heritabilities were averages of 20 estimates for each coagulation trait, and of 2 estimates for BCS and each of the type traits (Table 2). Additive genetic SD for RCT and $\mathrm{a}_{30}$ were 7.5 and $16.9 \%$ of their phenotypic mean, respectively. The value for $\mathrm{a}_{30}(16.9 \%)$ was much greater than that of other traits, which ranged from 0.9 (final score) to $8.5 \%$ (rump angle) of their phenotypic mean. These results confirm that MCP exhibit enough genetic variation to be improved through breeding.

Heritability estimates for RCT and $\mathrm{a}_{30}$ were 0.175 and 0.195 , respectively (Table 2). In an Estonian study, Vallas et al. (2010) analyzed repeated records of MCP measured by Optigraph on milk from first-lactation Holstein cows, and assessed heritabilities of 0.28 for log-transformed RCT and 0.41 for $\mathrm{a}_{30}$. Using data from Italian Holsteins, Cassandro et al. (2008) and Tiezzi et al. (2013) reported estimates of heritability that were 0.25 and 0.21 for RCT, and 0.15 and 0.24 for $\mathrm{a}_{30}$, respectively. Possible differences between our and the aforementioned studies may be related to (1) the use of multiparous cows and much higher number of samples in the case of Tiezzi et al. (2013), and (2) to the use of 
Table 2. Estimates ${ }^{1}$ of genetic standard deviation $\left(\sigma_{a}\right)$ and heritability $\left(h^{2}\right)$ for milk coagulation properties, linear type traits, final score, and BCS, and genetic correlations $\left(\mathrm{r}_{\mathrm{a}}\right)$ between milk coagulation properties and other traits ${ }^{2}$

\begin{tabular}{|c|c|c|c|c|}
\hline \multirow[b]{2}{*}{ Trait $^{3}$} & \multirow[b]{2}{*}{$\sigma_{\mathrm{a}}$} & \multirow[b]{2}{*}{$h^{2}$} & \multicolumn{2}{|c|}{$\mathrm{r}_{\mathrm{a}}$} \\
\hline & & & $\mathrm{RCT}$, min & $\mathrm{a}_{30}, \mathrm{~mm}$ \\
\hline \multicolumn{5}{|l|}{ Milk coagulation property } \\
\hline $\mathrm{RCT}, \mathrm{min}$ & 1.546 & 0.175 & & \\
\hline $\mathrm{a}_{30}, \mathrm{~mm}$ & 3.829 & 0.195 & & \\
\hline \multicolumn{5}{|l|}{ Frame } \\
\hline Stature & 2.258 & 0.199 & -0.253 & 0.198 \\
\hline Chest width & 1.502 & 0.123 & -0.237 & $0.317^{*}$ \\
\hline Body depth & 1.708 & 0.169 & $-0.382^{* *}$ & $0.386^{* *}$ \\
\hline Angularity & 1.755 & 0.172 & $-0.365^{* *}$ & $0.332 *$ \\
\hline Rump angle & 2.024 & 0.124 & $-0.338^{*}$ & 0.268 \\
\hline Rump width & 1.693 & 0.098 & -0.113 & 0.168 \\
\hline Conformation & 2.103 & 0.170 & $-0.306^{*}$ & 0.247 \\
\hline \multicolumn{5}{|l|}{ Feet and legs } \\
\hline Rear leg set side view & 0.859 & 0.024 & 0.316 & -0.297 \\
\hline Rear leg set rear view & 0.940 & 0.027 & -0.238 & 0.295 \\
\hline Foot angle & 0.970 & 0.040 & -0.184 & 0.173 \\
\hline Feet and legs functionality & 1.154 & 0.044 & -0.137 & 0.098 \\
\hline \multicolumn{5}{|l|}{ Udder } \\
\hline Fore udder attachment & 1.907 & 0.104 & -0.049 & -0.008 \\
\hline Rear udder height & 1.498 & 0.097 & -0.303 & 0.194 \\
\hline Udder depth & 2.289 & 0.111 & 0.049 & -0.150 \\
\hline Rear udder width & 1.150 & 0.067 & -0.273 & 0.298 \\
\hline Central ligament & 1.143 & 0.048 & -0.239 & 0.114 \\
\hline Front teat placement & 1.318 & 0.119 & 0.005 & -0.037 \\
\hline Teat length & 1.749 & 0.117 & -0.007 & -0.056 \\
\hline Final score & 0.717 & 0.140 & $-0.296^{*}$ & 0.205 \\
\hline BCS & 0.118 & 0.085 & 0.047 & -0.008 \\
\hline
\end{tabular}

${ }^{1}$ Standard errors of heritability estimates ranged from 0.001 to 0.044 ; standard errors of genetic correlation estimates ranged from 0.005 to 0.280 .

${ }^{2} \mathrm{~A}$ genetic correlation was considered significant if the associated genetic covariance was also significant according to log-likelihood ratio test.

${ }^{3} \mathrm{RCT}=$ rennet coagulation time; $\mathrm{a}_{30}=$ curd firmness 30 min after rennet addition.

${ }^{*} P<0.05 ;{ }^{*} P<0.01$.

multiparous cows and data measured once using a computerized renneting meter on a much smaller number of samples in the case of Cassandro et al. (2008).

Heritability estimates for linear type traits ranged from 0.024 (rear leg set side view) to 0.199 (stature). The heritability estimate of final score was 0.140 (Table 2 ). Overall, estimates obtained in the present study were lower than those reported in the literature (e.g., Pryce et al., 2000; Kadarmideen and Wegmann, 2003; Zink et al., 2011). For final score, Dechow et al. (2003) and Kadarmideen and Wegmann (2003) reported estimates of 0.24 and 0.22 in first-lactation Holsteins, which are higher than the value obtained in the present work (0.140).

Body condition score showed low heritability (0.085; Table 2), close to the estimate (0.114) reported by Battagin et al. (2013) on a much larger dataset of Italian Holstein cows. Pryce et al. (2000), Dechow et al. (2003), Kadarmideen and Wegmann (2003), and Zink et al. (2011) assessed heritabilities of $0.28,0.19,0.24$, and 0.30 , respectively, in first-parity Holsteins.
Genetic relationships of MCP with linear type traits, final score, and BCS were generally low and significance was found only for few estimates (Table 2). Genetic correlations of MCP with linear type traits ranged, in absolute value, from 0.005 (RCT and front teat placement) to 0.386 ( $\mathrm{a}_{30}$ and body depth). Final score was scarcely related with RCT $(-0.296)$ and $\mathrm{a}_{30}(0.205)$, and BCS was not related with MCP. On average, the highest and most significant genetic relationships were assessed between MCP and linear type traits belonging to "frame" (Table 2). Several authors estimated genetic correlations of MCP with milk production and quality traits (e.g., Cassandro et al., 2008; Vallas et al., 2010), but to our knowledge, no other studies that have attempted to estimate genetic relationships of MCP with linear type traits, final score, and BCS are currently available in the literature. Only, Kaart et al. (2010) investigated the relationships between MCP and traits other than milk yield and quality in Estonian Holstein cows. In particular, these authors found moderate to high and favorable relationships of $\mathrm{a}_{30}$ and log-trans- 
formed RCT with cow conception rate, and moderate to high and favorable correlations of MCP with logtransformed calving interval.

Overall, the findings of the present study suggest that MCP are weakly correlated with BCS and type traits, and thus MCP can be included in the selection index of the Italian Holstein-Friesian breed to enhance the coagulation ability of milk without detriment to BCS and aspects of conformation.

\section{ACKNOWLEDGMENTS}

Research was supported by Regione Veneto with the project "CheeseBull" (n. 2070868, Regolamento CE 1698/2005, Piano di Sviluppo Rurale del Veneto - Deliberazione della Giunta Regionale n. 1354 del 03/08/2011). The authors gratefully acknowledge the Italian Holstein Friesian Cattle Breeders Association (ANAFI, Cremona, Italy) for providing records on BCS and type traits, and for pedigree information, the laboratory of the Breeders Association of Veneto region (Padova, Italy) for data on milk coagulation properties, and Cristina Sartori (University of Padova, Italy) for useful insights into statistical analysis. The useful comments and suggestions provided by 2 anonymous reviewers are gratefully acknowledged.

\section{REFERENCES}

ANAFI. 2013. Genetic Evaluation Cards (in Italian). Accessed Jan 20, 2014. http://www.anafi.it/PubblicazioniAnafi/SchedeIndici_ ITA2013.pdf.

Battagin, M., F. Forabosco, J. H. Jakobsen, M. Penasa, T. J. Lawlor, and M. Cassandro. 2012. International genetic evaluation of Holstein bulls for overall type traits and body condition score. J. Dairy Sci. 95:4721-4731.

Battagin, M., C. Sartori, S. Biffani, M. Penasa, and M. Cassandro. 2013. Genetic parameters for body condition score, locomotion, angularity, and production traits in Italian Holstein cattle. J. Dairy Sci. 96:5344-5351.

Berry, D. P., F. Buckley, and P. Dillon. 2011. Relationship between live weight and body condition score in Irish Holstein-Friesian dairy cows. Ir. J. Agric. Food Res. 50:141-147.

Careau, V., M. E. Wolak, P. A. Carter, and T. Garland Jr.. 2013. Limits to behavioral evolution: The quantitative genetics of a complex trait under directional selection. Evolution 67:3102-3119.

Cassandro, M., A. Comin, M. Ojala, R. Dal Zotto, M. De Marchi, L. Gallo, P. Carnier, and G. Bittante. 2008. Genetic parameters of milk coagulation properties and their relationships with milk yield and quality traits in Italian Holstein cows. J. Dairy Sci. 91:371-376.

Cipolat-Gotet, C., A. Cecchinato, M. De Marchi, M. Penasa, and G. Bittante. 2012. Comparison between mechanical and near-infrared methods for assessing coagulation properties of bovine milk. J. Dairy Sci. 95:6806-6819.

De Marchi, M., M. Penasa, F. Tiezzi, V. Toffanin, and M. Cassandro. 2012. Prediction of milk coagulation properties by Fourier transform mid-infrared spectroscopy (FTMIR) for genetic purposes, herd management and dairy profitability. In 38th International Committee for Animal Recording (ICAR) Meeting, May 28 to June 1, Cork, Ireland. http://www.icar.org/Cork_2012/ Manuscripts/Published/Cassandro.pdf.
De Marchi, M., V. Toffanin, M. Cassandro, and M. Penasa. 2013. Prediction of coagulating and noncoagulating milk samples using mid-infrared spectroscopy. J. Dairy Sci. 96:4707-4715.

De Marchi, M., V. Toffanin, M. Cassandro, and M. Penasa. 2014. Invited review: Mid-infrared spectroscopy as phenotyping tool for milk traits. J. Dairy Sci. 97:1171-1186.

Dechow, C. D., G. W. Rogers, L. Klei, and T. J. Lawlor. 2003. Heritabilities and correlations among body condition score, dairy form and selected linear type traits. J. Dairy Sci. 86:2236-2242.

Edmonson, A. J., I. J. Lean, L. D. Weaver, T. Farver, and G. Webster. 1989. A body condition scoring chart for Holstein dairy cows. J. Dairy Sci. 72:68-78.

Hanford, K. J., L. D. Van Vleck, and G. D. Snowder. 2002. Estimates of genetic parameters and genetic change for reproduction, weight, and wool characteristics of Columbia sheep. J. Anim. Sci 80:3086-3098.

Ikonen, T., S. Morri, A.-M. Tyrisevä, O. Ruottinen, and M. Ojala. 2004. Genetic and phenotypic correlations between milk coagulation properties, milk production traits, somatic cell count, casein content, and pH of milk. J. Dairy Sci. 87:458-467.

Kaart, T., M. Vallas, A. Waldmann, H. Kiiman, K. Pärna, and E. Pärna. 2010. Associations between milk quality traits and coagulation properties and fertility in Estonian Holstein heifers and first lactation cows. Page 212 in Proceedings of the 9th World Congress on Genetics Applied to Livestock Production, Leipzig, Germany. German Society for Animal Science.

Kadarmideen, H. N., and S. Wegmann. 2003. Genetic parameters for body condition score and its relationship with type and production traits in Swiss Holsteins. J. Dairy Sci. 86:3685-3693.

Lynch, M., and B. Walsh. 1998. Genetics and Analysis of Quantitative Traits. Sinauer Associates Inc., Sunderland, MA.

Miglior, F., B. L. Muir, and B. J. Van Doormaal. 2005. Selection indices in Holstein cattle of various countries. J. Dairy Sci. 88:12551263

Misztal, I. 2008. Reliable computing in estimation of variance components. J. Anim. Breed. Genet. 125:363-370.

Morrissey, M. B., D. J. Parker, P. Korsten, J. M. Pemberton, L. E. B. Kruuk, and A. J. Wilson. 2012. The prediction of adaptive evolution: Empirical application of the secondary theorem of selection and comparison to the breeder's equation. Evolution 66:23992410 .

Penasa, M., M. Cassandro, D. Pretto, M. De Marchi, A. Comin, S. Chessa, R. Dal Zotto, and G. Bittante. 2010. Short communication: Influence of composite casein genotypes on additive genetic variation of milk production traits and coagulation properties in Holstein-Friesian cows. J. Dairy Sci. 93:3346-3349.

Penasa, M., F. Tiezzi, A. Sturaro, M. Cassandro, and M. De Marchi. 2014. A comparison of the predicted coagulation characteristics and composition of milk from multi-breed herds of Holstein-Friesian, Brown Swiss and Simmental cows. Int. Dairy J. 35:6-10.

Pretto, D., M. De Marchi, M. Penasa, and M. Cassandro. 2013. Effect of milk composition and coagulation traits on Grana Padano cheese yield under field conditions. J. Dairy Res. 80:1-5.

Pretto, D., T. Kaart, M. Vallas, I. Jõudu, M. Henno, L. Ancilotto, M. Cassandro, and E. Pärna. 2011. Relationships between milk coagulation property traits analyzed with different methodologies. J. Dairy Sci. 94:4336-4346.

Pryce, J. E., M. P. Coffey, and S. Brotherstone. 2000. The genetic relationship between calving interval, body condition score and linear type and management traits in registered Holsteins. J. Dairy Sci. $83: 2664-2671$

Pryce, J. E., M. P. Coffey, and G. Simm. 2001. The relationship between body condition score and reproductive performance. J. Dairy Sci. 84:1508-1515.

Pryce, J. E., R. J. Esslemont, R. Thompson, R. F. Veerkamp, M. A. Kossaibati, and G. Simm. 1998. Estimation of genetic parameters using health, fertility and production data from a management recording system for dairy cattle. Anim. Sci. 66:577-584.

Riddell-Lawrence, S., and C. L. Hicks. 1989. Effect of curd firmness on stirred curd cheese yield. J. Dairy Sci. 72:313-321. 
Tiezzi, F., D. Pretto, M. De Marchi, M. Penasa, and M. Cassandro. 2013. Heritability and repeatability of milk coagulation properties predicted by mid-infrared spectroscopy during routine data recording, and their relationships with milk yield and quality traits. Animal 7:1592-1599.

Vallas, M., H. Bovenhuis, T. Kaart, K. Pärna, H. Kiiman, and E. Pärna. 2010. Genetic parameters for milk coagulation properties in Estonian Holstein cows. J. Dairy Sci. 93:3789-3796.
Zink, V., M. Štípková, and J. Lassen. 2011. Genetic parameters for female fertility, locomotion, body condition score, and linear type traits in Czech Holstein cattle. J. Dairy Sci. 94:5176-5182. 